\title{
Performance of Stress Tolerant Rice Varieties Treated with Trichoderma spp. under Rainfed Condition in Bihar, India
}

\author{
Dinesh Rai* \\ Department of Plant Pathology, Dr. Rajendra Prasad Central Agricultural University, Pusa, \\ Samastipur-848125, Bihar, India \\ *Corresponding author
}

\section{A B S T R A C T}

In Bihar rice is a major food crop and has more than $5.14 \mathrm{M}$ ha area. Recent years environmental stress becoming major threats to rice cultivation and adversely affecting the productivity of crop. Drought resistance varieties and some microbes have proved their potential in mitigation of stresses and enhancing the rice yield under stress condition. In this study, two Trichoderma isolates were tested with three drought tolerant varieties i.e. Sahbaghi dhan, DRR44 and Neelam. The interaction effect between variety and treatment was significant. Trichoderma treated seed enhanced both growth and yield attributes in rice compared to untreated. Variety i.e. Sahbhjagi dhan + (T1) Trichoderma isolate 1 gave maximum grain $(42.50 \mathrm{q} / \mathrm{ha})$, followed by Sahbhagi dhan $+(\mathrm{T} 2)$ Trichoderma isolate 2 (41.84 q/ha) and then DRR44 + (T1) Trichoderma isolate 1 (39.60 q/ha), DRR44 + (T2) Trichoderma isolate $2(38.93 \mathrm{q} / \mathrm{ha})$ under stress condition. The minimum grain yield $(30.20 \mathrm{q} / \mathrm{ha})$ was obtained from drought susceptible variety i.e. IR 64 under stress without seed treatment with Trichoderma. The results of this present work could be advised in drought prone area to alleviate stresses under field condition.

\section{Introduction}

Rice (Oryza sativa L) is the major source of food and income for millions of people in India. Worldwide, more than 3.5 billion people depend on rice and more than $90 \%$ of rice is grown and consumed in Asia where $60 \%$ of people on the earth live. More than $75 \%$ of the annual rice supply comes from 79 million ha of irrigated paddy land. Thus present and future food security of Asia depends largely on the irrigated rice production system. However, rice is a profligate user of water. It takes 3000-5000 liters to produce 1 kilogram of rice, which is about 2 to 3 times more than to produce 1 kilogram of other cereals such as wheat or maize (Bouman et al., 2002). In Asia abiotic and bioric stress becoming major threat to rice cultivation and adversely affecting the productivity of crop under climate changing scenario. The production of rice is increasingly limited by various environmental stresses with about $30 \%$ of the 700 million poor affected in rainfed lowlands of Asia alone (Dar et al., 2013). Drought, submergence and the sequential events (drought followed by submergence and vice- 
versa) are the major constraints for rice production in such areas (Fukao et al., 2011). In India, approximately $13.6 \mathrm{M}$ ha of area under rice is affected from drought of varying intensities (Singh et al., 2016). Stress environment induces a number of physiological, biochemical and molecular changes within plants which governs growth and productivity. The incidence, intensity and duration of environmental stresses have posed a serious threat to agricultural productivity and food security across the globe (Jones et al., 2014).

In Bihar rice is premier food crop and 5.4 M ha of area under rice, which has an average productivity of only $1.2 \mathrm{t} / \mathrm{ha}$. More than half of the rice area is rainfed lowland, including flood-prone ecosystems, which are characterised by low productivity obtained under traditional systems of cultivation. Bihar often faces the drought situation of different scales/levels. This situation necessarily occurs when the summer mansoon gets weak and causes the departure of the seasonal rainfall from the normal. Water deficit, more commonly referred to as 'drought', has been, and continues to be the most limiting factor affecting rice production, especially in areas with inadequate agriculture water resources (Xiao et al., 2008). Therefore, with the global shortage of water, reducing water consumption in crop production is recognized as an essential strategy for sustainable agriculture (Xiao et al., 2008). Rice grain yield and yield components have been known to be highly influenced by water supply. Use of yield as an index for adaptation to drought stress in rice (Atlin, 2001) may be considered as a reasonable approach, as grain yield is a major attribute of interest in most plant breeding programs (Pantuwan et al., 2004). However, drought tolerance is a complex trait that involves various aspects of developmental, physiological, biochemical, and molecular adjustments. Plants under drought condition survive by doing a balancing act between maintenance of turgor and reduction of water loss. Drought tolerant varieties i.e. Sahbhagi Dhan, CR Dhan 405, Sushk Samrat and Abhishek have been recognized to stabilize rice productivity in the rainfed lowlands of eastern India including Bihar (Ismail et al., 2013). There is always the scope of further improvement by manipulating management practices especially under multiple stress conditions (Doni et al., 2014). Recent studies have proved potential of microorganisms against abiotic and biotic stress. Trichoderma spp. is a common component of rhizosphere soil and has been reported to suppress a great number of plant diseases, some strains, also, have been reported to colonize the root surface, enhancing root growth and development, crop productivity, resistance to abiotic stresses, and the uptake and use of nutrients (MartínezMedina et al., 2011). In the present study two Trichoderma isolates were tested with three stress tolerance varieties under rainfed condition in Bihar.

\section{Materials and Methods}

The experiment was conducted during Kharif 2017 at the Research farm of Dr. Rajendra Prasad Central Agricultural University, Pusa, Samastipur, Bihar. The Experimental farm is located at an altitude of 52.0 meter from mean sea level, at latitude of $25.98^{\circ} \mathrm{N}$ and longitude of $85.67^{0} \mathrm{E}$. The climate is sub-humid type and monsoon receiving an average annual rainfall of $1234.7 \mathrm{~mm}$ mainly during the months - June to October. The experimental plot had a uniform topography. Soil was sandy loam well drained and medium fertility. The plot size was $5 \times 5 \mathrm{~m}^{2}$. Field was ploughed then labelled. The experiment consisting of a total 16 treatments was laid out in a Factorial Randomized Block Design with three replications. After layout of experiment, sowing was done on 30 June, 2018. 
Recommended fertilizer dose i.e.110:50:30 were applied. The weeds were removed manually after 45 and 75 days of sowing. The data regarding growth and yield attributes including plant height, number of tillers $/ \mathrm{m}^{2}$; panicle $/ \mathrm{m}^{2}$, total grains/panicle, filled grains/ panicle, unfilled grains/ panicle, grain yield and brown disease severity were recorded during the investigation at harvest.

\section{Treatment details}

\section{Varieties}

V1-Sahbhagi Dhan (Drought tolerant)

V2-DRR44 (Drought tolerant)

V3-Nelam (Drought tolerant)

V4-IR-64 (Drought susceptible)

\section{Treatment}

T1- Seed treatment with Trichoderma Formulation (IRRI isolate 1) @ 10g/kg seed

T2- Seed treatment with Trichoderma Formulation (IRRI isolate 2) @ 10g/kg seed

T3- Sowing of normal water seed soaked variety (Drought stress

T4- Sowing of normal water seed soaked variety (No stress)

\section{Application of Trichoderma isolates}

Trichoderma isolates were received under the project the STRASA (Stress Tolerant Rice for Africa and South Asia (IRRI), New Delhi, India. Seeds are taken of each treatment and kept for water soaking for $24 \mathrm{hr}$.

After water soaking, bio-control agent treatment was given @ $10 \mathrm{gm} / \mathrm{kg}$ seed and applied next day to the seed and untreated seed served as control. All the operations were done in shade and one day before sowing.

\section{Drought creation}

Direct seeded rice method was used for the sowing of treated and untreated seeds and maintained by applying irrigation; day until plants attained the age of five weeks and at this point drought treatment as given by altering the water cycle. Watering was stopped for subsequent days for each drought treatment which included 4, 7, 10 and 13 days drought stress (DDS), while control seedlings plots received water every alternate day. Between the two days drought stress period i.e. 10 and 13 were disturbed by rain but drain out the water from the field.

\section{Results and Discussion}

Results of the experiment showed that rice varieties, Trichoderma isolates and their interactions have significant influenced on yield under stress condition. Seed bioprimed with Trichoderma isolate has a significant effect on rice growth and yield attributes.

\section{Plant height (cm)}

The results related to plant height has been presented in Table 1. The statistical analysis showed significant differences among the varieties and treatments but their interaction was not found significant in plant height at harvest. Among the different varieties, the maximum plant height was observed in Neelam $(110.10 \mathrm{~cm})$ followed by Sahbhagi Dhan (104.52 cm), DRR44 (96.57) and IR 64 (94.90). In case of the treatments, maximum plant height $(105.00 \mathrm{~cm})$ was observed in (T1) Trichoderma isolate 1 followed by (T2) Trichoderma isolate 2 but both were at par with each other. The minimum plant height $(97.22 \mathrm{~cm})$ was observed under stress condition (T4). The results indicate that varieties $\mathrm{x}$ treatments interactions did not bring about any significant changes in the plant height. Plant height was significantly 
affected by water stress and Trichoderma. This result is agrees with Islam et al., (1994) who found that moisture stress reduced plant height at $20 \%$ soil saturation. Some previous studies have also reported that the application of Trichoderma enhances the growth and grain yield in rice under stress conditions (Gusain et al., 2014; Bae et al., 2009) Baker et al., (1988) stated that plant growth responses induced by Trichoderma spp. appeared to be due to both the control of minor pathogens and production of a growth-regulating factor. Windham et al., (1986) stated that this fungus may produce a growth promotion substance such as exudation of plant growth stimulating factors and phytohormones like indole acetic acid (IAA) and their analogs and vitamins. Zaidi et al., (2018) reported similar type of observations on plant height in the Sahbhagi dhan under rainfed condition in Bihar.

\section{Number of Tillers/ $\mathbf{m}^{2}$}

The number of tillers was counted treatments wise at the harvest. The data were statistically computed and mean and data are presented in Table 1. In case of different varieties, the maximum number of tiller was observed with Sahbhagi dhan (301.50 tillers/ $\mathrm{m}^{2}$ ) followed by DRR44 $\left(287.58 / \mathrm{m}^{2}\right)$ and Neelam (269.00/ $\mathrm{m}^{2}$ ) and these were at par with each other. The lowest tillers count $\left(247.75 / \mathrm{m}^{2}\right)$ was noted in the IR 64.

In different treatments it ranged from 231.42 to $298.92 / \mathrm{m}^{2}$. As regards with the treatments effect, the number of tillers enhanced significantly due to increase due to Trichoderma at harvest. The maximum tillers $\left(298.92 / \mathrm{m}^{2}\right)$ was observed in (T1) Trichoderma isolate 1 followed by (T2) Trichoderma isolate $2\left(294.83 / \mathrm{m}^{2}\right)$, (T4) No stress $\left(280.67 / \mathrm{m}^{2}\right)$ and these were at par with each other. The minimum tillers $\left(231.42 / \mathrm{m}^{2}\right)$ were observed under stress condition in (T4). The interaction effect between variety $x$ treatment on number tiller was found significant and maximum tillers $\left(346.33 / \mathrm{m}^{2}\right)$ was observed in variety Shbhagi dhan with (T1) treated with Trichoderma isolate 1 and this was at par with other varieties with both the isolates under stress condition. However, tillers formation in varieties under stress condition treated with Trichoderma isolates and tillers count in varieties under no stress were at par with each other. The significant lowest tillers formation count was noted in IR64 $\left(216.00 / \mathrm{m}^{2}\right)$ under stress condition. The present finding is supported by Doni et al., (2014) who reported that Trichoderma strain SL2 treated rice plants exhibited greatest increase in plant height and tiller number, while Trichoderma strain SL7 had the greatest effect in enhancing the number of leaves.

\section{Number of panicles/ $\mathbf{m}^{2}$}

The panicles/ $\mathrm{m}^{2}$ were counted treatment wise and the data so obtained were statistically analyzed and the mean data are presented in Table 2. The different Trichoderma isolates as well as varieties were found to exert significant influence upon this yield attributing parameter. However, the Trichoderma $\mathrm{x}$ variety interactions were found to be significant.

Among the varieties, Sahbhagi dhan resulted in significantly higher panicles count (254.92/ $\left.\mathrm{m}^{2}\right)$ as compared to DRR44 (247.00/ $\left.\mathrm{m}^{2}\right)$, Neelam $\left(242.25 / \mathrm{m}^{2}\right)$ and IR64 $\left(212.17 / \mathrm{m}^{2}\right)$. That means the other varieties at par performed to that of Sahbhagi dhan with respect to the formation of panicles except IR 64.

The use of Trichoderma increased the panicles formation significantly. Thus the maximum panicles $\left(260.83 / \mathrm{m}^{2}\right)$ were recorded from (T1) Trichoderma isolate 1, followed by (T2) Trichoderma isolate $2(259.00 / \mathrm{m} 2)$ and both were at par with each other. The significantly 
lowest 194.33 panicles/ $\mathrm{m} 2$ from (T3) under stress. The interaction effect between variety $\mathrm{x}$ treatment on number of panicles $/ \mathrm{m}^{2}$ was found significant and maximum panicles (286.67/ $\mathrm{m}^{2}$ ) was observed in variety Shbhagi dhan with treated (T1) Trichoderma isolate 1 followed by variety DRR44 $\left(284.33 / \mathrm{m}^{2}\right)$ with treated (T1) Trichoderma isolate 1, Shbhagi dhan $\left(282.00 / \mathrm{m}^{2}\right)$ with treated (T2) Trichoderma isolate 2 and variety DRR44 $\left(275.67 / \mathrm{m}^{2}\right)$ with treated (T2) Trichoderma isolate 2 under stress condition and these were at par with each other. The significant lowest panicles formation count was noted in IR6 $\left(171.66 / \mathrm{m}^{2}\right)$ under stress condition. Several workers reported that Trichoderma spp under any stress enhances root growth, helps in water absorption and improves the nutrient uptake (Howell, 2003; Harman et al., 2004; Contreras-Cornejo et al., 2009, Chen et al., 2013, Zaidi et al., 2018) resulted increased growth and yield attributing characters. Trichoderma also make the available form of nutrient by secreting some organic acid and other substances.

\section{Number of grains /panicle}

The results related to number of grains presented in Table 2. Number of grains/ panicle ranged from 145.16 to 184.66 and 150.33 to 187.17 in varieties and treatments respectively. The statistical analysis showed significant differences among genotypes, treatments and their interaction. Among the varieties, the maximum grain / panicle (184.66) were observed in Sahbhagi dhan followed by Neelam (180.83 grains/ panicle) and both were at par with each other. The minimum grains/panicle (145.16) was observed in IR 64. The use of Trichoderma increased the grains formation/ panicle significantly. The maximum grains (184.17/panicle) were recorded from (T1) Trichoderma isolate 1, followed by (T2) Trichoderma isolate 2 (175.00/ panicle). The significantly lowest 80.33 grains /panicle from (T3) under stress. The interaction effect between variety $\mathrm{x}$ treatment on number of grains/panicle was found significant and maximum grains (207.33/ panicle) was observed in variety Shbhagi dhan with treated (T1) Trichoderma isolate 1 followed by Neelam (200.33/ panicle) with treated (T1) Trichoderma isolate 1 , and both were at par with each other.

The significant lowest grains formation per panicle count was noted in IR6 (216.00/ panicle) under stress condition. The present finding is supported by Puja Kumari (2016) who reported significantly maximum panicle/ $\mathrm{m}^{2}$ with seed treated Trichoderma harzianum in rice under stress condition compared to control.

\section{Number of filled grains/panicle}

The filled grains/panicle were observed and counted and the mean data are presented in Table 3. The statistical analysis showed significant differences among genotypes, treatments and their interaction. Total filled grains/ panicles ranged from 98.17 to 149.25 and 97.92 to 146.83 in varieties and treatments respectively.

Among the varieties, the maximum filled grains / panicle (149.25) was observed in Sahbhagi dhan followed by Neelam (135.33 filled grains/ panicle), DRR 44 (131.42 filled grains/ panicle). The minimum filled grains/panicle (98.17/ panicle) was observed in IR 64 under stress without seed treated with Trichoderma. The maximum filled grains (146.83/ panicle) were recorded from (T1) Trichoderma isolate 1, followed by (T2) Trichoderma isolate 2 (139.41/ panicle) and both were at par with each other under stress condition. The significantly lowest 97.92 filled grains /panicle from (T3) under stress without seed treatment with Trichoderma. 
Table.1 Average plant height and tillers of rice varieties as influenced by Trichoderma isolates

\begin{tabular}{|c|c|c|c|c|c|c|c|c|c|c|c|}
\hline & \multicolumn{5}{|c|}{ Plant height $(\mathrm{cm})$} & \multicolumn{6}{|l|}{ Tillers/ $\mathrm{m}^{2}$} \\
\hline Varieties & $\begin{array}{l}\text { T1 (Stress } \\
+ \text { IRRI } \\
\text { isolate 1) }\end{array}$ & $\begin{array}{l}\text { T2 (Stress } \\
+ \text { IRRI isolate } \\
\text { 2) }\end{array}$ & $\begin{array}{l}\text { T3 } \\
\text { (Stress) }\end{array}$ & T4 (No Stress) & Mean & $\begin{array}{l}\text { T1 (Stress } \\
+ \text { IRRI } \\
\text { isolate 1) }\end{array}$ & \multicolumn{2}{|c|}{$\begin{array}{l}\text { T2 (Stress } \\
+ \text { IRRI isolate } \\
\text { 2) }\end{array}$} & T3 (Stress) & $\begin{array}{l}\text { T4 (No } \\
\text { Stress) }\end{array}$ & Mean \\
\hline Sahbhagi Dhan & 108.93 & 105.87 & 100.60 & 102.67 & 104.52 & 346.33 & 317.67 & & 251.00 & 291.00 & 301.50 \\
\hline DRR44 & 100.40 & 98.53 & 92.20 & 95.13 & 96.57 & 326.67 & 305.67 & & 238.00 & 280.00 & 287.58 \\
\hline Neelam & 113.67 & 115.33 & 104.00 & 107.47 & 110.12 & 270.00 & 315.67 & & 220.67 & 269.67 & 269.00 \\
\hline IR64 & 97.00 & 94.87 & 92.07 & 95.67 & 94.90 & 252.67 & 240.33 & & 216.00 & 282.00 & 247.75 \\
\hline Mean & 105.00 & 103.65 & 97.22 & 100.23 & & 298.92 & 294.83 & & 231.42 & 280.67 & \\
\hline & Variety & \multicolumn{2}{|c|}{ Treatment } & \multicolumn{2}{|l|}{ Variety X Treatment } & \multicolumn{2}{|l|}{ Variety } & \multicolumn{2}{|c|}{ Treatment } & \multicolumn{2}{|c|}{ Variety X Treatment } \\
\hline $\mathrm{CD}(\mathrm{P}=0.05)$ & 4.21 & \multicolumn{2}{|c|}{4.21} & \multicolumn{2}{|l|}{ NS } & \multicolumn{2}{|l|}{38.26} & \multicolumn{2}{|c|}{38.26} & \multicolumn{2}{|c|}{76.53} \\
\hline CV\% & \multicolumn{5}{|c|}{5.07} & \multicolumn{6}{|c|}{16.60} \\
\hline
\end{tabular}

Table.2 Average panicles and total grain of rice varieties as influenced by Trichoderma isolates

\begin{tabular}{|c|c|c|c|c|c|c|c|c|c|c|}
\hline \multirow[b]{2}{*}{ Varieties } & \multicolumn{5}{|c|}{ Panicles/ $\mathrm{m}^{2}$} & \multicolumn{5}{|c|}{ Total grain /panicle } \\
\hline & $\begin{array}{l}\text { T1 (Stress } \\
\text { +IRRI } \\
\text { isolate 1) }\end{array}$ & $\begin{array}{l}\text { T2 (Stress } \\
\text { +IRRI } \\
\text { isolate 2) }\end{array}$ & T3 (Stress) & $\begin{array}{l}\text { T4 (No } \\
\text { Stress) }\end{array}$ & Mean & $\begin{array}{l}\text { T1 (Stress } \\
\text { +IRRI } \\
\text { isolate1) }\end{array}$ & $\begin{array}{c}\text { T2 (Stress } \\
\text { +IRRI isolate } \\
\text { 2) }\end{array}$ & T3 (Stress) & T4 (No Stress) & Mean \\
\hline Sahbhagi Dhan & 286.67 & 282.00 & 206.33 & 244.67 & 254.92 & 207.33 & 192.67 & 163.00 & 175.67 & 184.66 \\
\hline DRR44 & 284.33 & 275.67 & 194.67 & 233.33 & 247.00 & 183.33 & 178.33 & 146.33 & 153.67 & 165.42 \\
\hline Neelam & 255.67 & 261.33 & 204.67 & 247.33 & 242.25 & 200.33 & 188.33 & 158.00 & 176.67 & 180.83 \\
\hline \multirow[t]{2}{*}{ IR64 } & 216.67 & 217.00 & 171.66 & 243.33 & 212.17 & 145.67 & 140.67 & 134.07 & 160.33 & 145.16 \\
\hline & 260.83 & 259.00 & 194.33 & 242.17 & & 184.17 & 175.00 & 150.33 & 166.58 & \\
\hline
\end{tabular}

\begin{tabular}{|c|c|c|c|c|c|c|}
\hline & Variety & Treatment & Variety X Treatment & Variety & Treatment & Variety $\mathbf{X}$ Treatment \\
\hline $\mathbf{C D}(\mathbf{P}=\mathbf{0 . 0 5})$ & 17.20 & 17.20 & 34.40 & 8.91 & 17.84 \\
\hline $\mathbf{C V} \%$ & & 8.63 & & & 6.32 \\
\hline
\end{tabular}


Table.3 Average filled and unfilled grain of rice varieties as influenced by Trichoderma isolates

\begin{tabular}{|c|c|c|c|c|c|c|c|c|c|c|}
\hline \multirow[b]{2}{*}{ Varieties } & \multicolumn{5}{|c|}{ Filled grain /panicle } & \multicolumn{5}{|c|}{ Unfilled grain /panicle } \\
\hline & $\begin{array}{l}\text { T1 (Stress } \\
\text { +IRRI } \\
\text { isolate 1) }\end{array}$ & $\begin{array}{c}\text { T2 (Stress } \\
+ \text { IRRI isolate } \\
\text { 2) }\end{array}$ & $\begin{array}{c}\mathrm{T} 3 \\
\text { (Stress) }\end{array}$ & $\begin{array}{l}\text { T4 (No } \\
\text { Stress) }\end{array}$ & Mean & $\begin{array}{c}\text { T1 (Stress } \\
+ \text { IRRI isolate } \\
\text { 1) }\end{array}$ & $\begin{array}{c}\text { T2 (Stress } \\
+ \text { IRRI isolate } \\
\text { 2) }\end{array}$ & T3 (Stress) & $\begin{array}{l}\text { T4 (No } \\
\text { Stress) }\end{array}$ & Mean \\
\hline Sahbhagi Dhan & 173.33 & 163.33 & 114.67 & 145.67 & 149.25 & 34.00 & 29.33 & 48.33 & 30.00 & 35.42 \\
\hline DRR44 & 152.33 & 145.67 & 105.33 & 122.33 & 131.42 & 31.33 & 32.00 & 41.00 & 31.33 & 33.92 \\
\hline Neelam & 156.00 & 147.00 & 102.00 & 136.33 & 135.33 & 44.33 & 41.33 & 56.00 & 40.33 & 45.50 \\
\hline \multirow[t]{2}{*}{ IR64 } & 102.67 & 101.67 & 69.67 & 118.67 & 98.17 & 43.00 & 39.00 & 64.33 & 41.67 & 47.00 \\
\hline & 146.83 & 139.41 & 97.92 & 130.75 & & 38.16 & 35.42 & 52.41 & 35.83 & \\
\hline
\end{tabular}

\begin{tabular}{|c|c|c|c|c|c|c|c|}
\hline & Variety & Treatment & Variety X Treatment & Variety & Treatment & Variety X Treatment \\
\hline $\mathbf{C D}(\mathbf{P}=\mathbf{0 . 0 5})$ & 8.71 & 8.71 & 17.44 & 4.32 & 8.64 \\
\hline $\mathbf{C V} \%$ & & 8.13 & & & 12.80 \\
\hline
\end{tabular}

Table.4 Average severity of brown spot and grain yield of rice varieties as influenced by Trichoderma isolates

\begin{tabular}{|c|c|c|c|c|c|c|c|c|c|c|}
\hline \multirow[b]{2}{*}{ Varieties } & \multicolumn{5}{|c|}{ Severity of Brown spot } & \multicolumn{5}{|c|}{ grain yield q/ha } \\
\hline & $\begin{array}{l}\text { T1 (Stress } \\
\text { +IRRI } \\
\text { isolate 1) }\end{array}$ & $\begin{array}{c}\text { T2 (Stress } \\
\text { +IRRI isolate } \\
\text { 2) }\end{array}$ & $\begin{array}{c}\mathrm{T} 3 \\
\text { (Stress) }\end{array}$ & $\begin{array}{l}\text { T4 (No } \\
\text { Stress) }\end{array}$ & Mean & $\begin{array}{c}\text { T1 (Stress } \\
\text { +IRRI isolate } \\
\text { 1) }\end{array}$ & $\begin{array}{c}\text { T2 (Stress } \\
\text { +IRRI isolate } \\
\text { 2) }\end{array}$ & T3 (Stress) & $\begin{array}{l}\text { T4 (No } \\
\text { Stress) }\end{array}$ & Mean \\
\hline Sahbhagi Dhan & $\begin{array}{c}21.67 \\
(27.71)\end{array}$ & $\begin{array}{c}23.33 \\
(28.85)\end{array}$ & $\begin{array}{c}33.33 \\
(35.25)\end{array}$ & $\begin{array}{c}28.33 \\
(32.14)\end{array}$ & $\begin{array}{c}26.67 \\
(30.98)\end{array}$ & 42.50 & 41.60 & 35.53 & 37.67 & 39.33 \\
\hline DRR44 & $\begin{array}{c}21.00 \\
(27.27)\end{array}$ & $\begin{array}{c}23.33 \\
(28.85)\end{array}$ & $\begin{array}{c}31.67 \\
(34.23)\end{array}$ & $\begin{array}{c}27.33 \\
(31.48)\end{array}$ & $\begin{array}{c}25.83 \\
(30.45)\end{array}$ & 39.60 & 38.93 & 33.17 & 35.70 & 36.85 \\
\hline Neelam & $\begin{array}{c}28.33 \\
(32.15)\end{array}$ & $\begin{array}{c}31.67 \\
(34.23)\end{array}$ & $\begin{array}{c}38.67 \\
(38.44)\end{array}$ & $\begin{array}{c}33.33 \\
(35.25)\end{array}$ & $\begin{array}{c}33.00 \\
(35.20)\end{array}$ & 38.57 & 38.07 & 31.93 & 34.73 & 35.83 \\
\hline \multirow[t]{2}{*}{ IR64 } & $\begin{array}{c}35.00 \\
(36.27)\end{array}$ & $\begin{array}{c}36.67 \\
(37.26)\end{array}$ & $\begin{array}{c}39.33 \\
(38.84)\end{array}$ & $\begin{array}{c}36.67 \\
(37.26)\end{array}$ & $\begin{array}{c}36.92 \\
(37.41)\end{array}$ & 33.60 & 32.98 & 30.20 & 35.57 & 33.09 \\
\hline & $\begin{array}{c}26.50 \\
(30.84)\end{array}$ & $\begin{array}{c}28.75 \\
(32.30)\end{array}$ & $\begin{array}{c}35.75 \\
(36.70)\end{array}$ & $\begin{array}{c}31.42 \\
(34.03)\end{array}$ & & 38.57 & 37.90 & 32.70 & 35.92 & \\
\hline
\end{tabular}

\begin{tabular}{|c|c|c|c|c|c|c|c|}
\hline & Variety & Treatment & Variety X Treatment & Variety & Treatment & Variety X Treatment \\
\hline $\mathbf{C D}(\mathbf{P}=\mathbf{0 . 0 5})$ & $2.31(1.47)$ & $2.31(1.47)$ & 4.62 & 1.83 & 3.63 \\
\hline $\mathbf{C V} \%$ & & $9.08(5.28)$ & & & 6.03 \\
\hline
\end{tabular}


The interaction effect between variety $x$ treatment on number of filled grains/panicle was found significant and maximum filled grains (173.33/panicle) was observed in variety Shbhagi dhan with treated (T1) Trichoderma isolate 1 followed by variety Shbhagi dhan (163.33/panicle) with treated (T2) Trichoderma isolate 2 and Neelam (156.00/panicle) with treated (T1) Trichoderma isolate 1 . The minimum filled grains / panicle (69.67) was noted in IR64 (216.00/ panicle) under stress without seed treated with Trichoderma. These results are in agreement with the findings of Zaidi et al., (2018) who reported that the application of Trichoderma (S2) enhances panicle weight, number of filled grains per panicle and grain yield in rice under stress.

\section{Number of unfilled grains/panicle}

The unfilled grains /panicle were also observed and counted treatment wise and the data were subjected to statistical analysis. The mean values are exhibited in Table 3 . The different varieties showed significant differences in their unfilled grains/ panicle. The minimum unfilled grains / panicle (33.92) was noted in DRR44 followed by Shbhagi dhan (35.42 filled grains/ panicle) and both were at par with each other, whereas IR - 64 recorded significantly higher unfilled grains (47.00 filled grain /panicle).

Among the treatments, significant maximum unfilled grains/ panicle (35.44) was recorded in (T2) Trichoderma isolate 2 followed by (T1) Trichoderma isolate 1 (38.16 unfilled grains/ panicle) but both were at par with each other. The maximum unfilled grains/ panicle (52.41) was observed in IR 64 under stress condition without untreated seed of Trichoderma. The interaction effect between variety $\mathrm{x}$ treatment on number unfilled grains/panicle was found significant and minimum unfilled grains (29.33/panicle) was observed in variety Shbhagi dhan with treated (T2) Trichoderma isolate 1 followed by variety DRR44 (31.33/panicle) with treated (T2) Trichoderma isolate 2 and DRR 44 (32.00/panicle) with treated (T2) Trichoderma isolate 2 and these were at par with each other under stress with seed treatment with Trichoderma. The maximum unfilled grains / panicle (64.33) was noted in IR64 under stress without seed treated with Trichoderma. Similar finding also reported by Puja Kumari (2016) who observed significantly maximum unfilled grains/panicle in rice variety IR 64 under stress condition.

\section{Brown spot disease severity on rice}

The severity of brown spot disease of rice is recorded and data are presented in Table 4. Brown spot disease severity was low in all the varieties compared to untreated. The different varieties showed significant differences in their disease severity. Among the varieties, significant minimum disease severity (25.83\%) was recorded in DRR44 followed by Sahbhagi dhan (26.67\%) and both were at par with each other. The maximum brown spot disease severity was noted in IR 64 $(36.92 \%)$.

The minimum disease severity $(26.50 \%)$ was recorded with (T1) Trichoderma isolate 1 followed by (T2) Trichoderma isolate 2 $(28.75 \%)$ but both were at par with each other. The maximum brown spot disease severity (35.75\%) was observed in (T3) under stress and untreated seed. The interaction effect between variety $\mathrm{x}$ treatment on brown spot disease severity was significant and minimum disease severity $(21.00 \%)$ was observed in variety DRR44 with treated (T1) Trichoderma isolate 1 followed by variety Sahbhagi dhan (21.67\%)) with treated (T1) Trichoderma isolate 1, Sahbhagi dhan $(23.33 \%)$ ) with treated (T1) Trichoderma isolate 1and DRR $44(23.33 \%)$ with treated 
(T2) Trichoderma isolate 2. All these were at par with each other under stress with seed treatment with Trichoderma. Similarly, Harish et al., (2007) stated that spraying of spore suspension of Trichoderma isolates on rice plant significantly inhibited the growth and spore germination of $B$. oryzae besides increasing seedling growth. Kumawat et al., (2008) also found that pre-application of spore suspension of $T$. harzianum and $T$. viride reduced the infection of $B$. oryzae, which was attributed to increased level of total soluble protein and total phenol contents.

\section{Grain yield}

The results related to grain yield has been presented in Table 4 and the grain yield $q /$ ha was obtained from after converting the plot wise yield under different treatments. The Trichoderma isolates as well as varieties exerted significant impact upon the grain yield. The statistical analysis showed significant differences among genotypes treatments and also the interaction between genotypes and treatments was found significant. Among the varieties, significant maximum grain yield (39.33q/ ha) followed by DRR44 (36.85 q/ ha and Neelam (35.83q/ ha). However DRR44 and Neelam were at par with each other. Significantly lowest grain yield (33.09 q/ ha) was observed in IR 64. The treatment interactions were found to be significant, however Sahbhjagi dhan + (T1) Trichoderma isolate 1 produced the maximum grain (42.50 q/ ha), followed by Sahbhagi dhan + (T2) Trichoderma isolate $2(41.84 \mathrm{q} /$ ha) and then DRR44 + (T1) Trichoderma isolate 1 (39.60 q/ ha), DRR44 + (T2) Trichoderma isolate 2 (38.93 q/ ha). The minimum grain yield (30.20 q/ ha) was obtained from IR 64+ (T3) under stress in untreated with Trichoderma. Pantuwan et al., (2001) reported that the drought tends to delay the flowering and higher delay in rice was associated with low grain yield and harvest index. These yield components were very much governed by chaffy seeds and less fertile grains. The application of some microbial formulations has the potential to enhance the stress mitigating effects of rice varieties. On-station evaluation results suggested that the application of some of the microbial formulations either exclusively or in combination with FYM had positive effect on yield and yield parameters of drought tolerant rice variety Sahbhagi dhan (Zaidi et $a l ., 2018$ ). Some previous studies have also reported that the application of Trichoderma enhances the growth and grain yield in rice under stress conditions (Gusain et al., 2014; Bae et al., 2009). The high yield associated with potassium application may be due to its greater uptake and active participation in all structure, carbon assimilation, photosynthesis, starch formation, translocation of protein and sugar, entry of water into plants root and development etc. The possible reason of enhancement in yield attributes may be due to these facts. These microbes reduced disease infestation, secretes organic acid which converted insoluble form of nutrient to soluble form and also provided some additional micro nutrient, vitamins, auxin etc. hydrogel solution provides medium to absorb these compound by eliminating water stress condition. Higher amount of nutrient was taken up by the plant which increases photosynthetic ability, photosynthetate translocation and accumulation. In conclusion, drought tolerant variety Sahbhagi dhan treated with Trichoderma isolate 1 could be a better option in the drought affected districts of Bihar and we can get significant more yield compared to drought susceptible varieties.

\section{Acknowledgements}

The author is highly grateful to Dr. U.S. Singh and Dr. N.W. Zadi, Scientist, International Rice Research Institute (IRRI), 
India Office, New Delhi, India for their kind support under STRASA, Project, especially in terms fund and providing Trichoderma isolates.

\section{References}

Atlin, G.N. (2001). Breeding for Suboptimal Environments. In: Shu, F., Jaya, B. (eds.) Increased Lowland Rice Production in the Mekong Region. Proceeding of the International Workshop, Vientiane, Laos, 30 October- 2 November 2000. ACIAR Canberra, p245-251.

Bae, H., Sicher, R.C., Kim, M.S., Kim, S.H., Strem, M.D., Melnick, R.L. and Bailey, B.A. (2009). The beneficial endophyte Trichoderma hamatum isolate DIS $219 \mathrm{~b}$ promotes growth and delays the onset of the drought response in Theobroma cacao. J. Exp. Bot. 60 (11): 3279-3295.

Baker, R. (1988). Trichoderma spp. As plant growth stimulants, CRC, Critical Rev., 7:97.

Bauman, B.A.M., H. Hengsdijk, B. Hardy P.S. Bindraban, T.P. Tuong, J.K. Ladha, Editors, (2002). Water-wise rice production. Proceeding of the International workshop on water wise rice production 8-11April 2002, Los Banos, Philippines. Los Banos (Philippins): International Rice Research Institute. pp: 356

Chen, Q., Tao, S., Bi, X., Xu, X., Wang, L., An and Li, X. (2013). Research progress in physiological and molecular biology mechanism of drought resistance in rice. Am. J. Mol. Biol. 3: 102- 07.

Contreras-Cornejo, H.A., Macias-Rodriguez, L., Cortes-Penagos, C. and LopezBucio, J. (2009). Trichoderma virens, a plant beneficial fungus, enhances biomass production and promotes lateral root growth through an auxin- dependent mechanism in Arabidopsis. Plant Physiol. 149: 1579-1592.

Dar, M.H., de Janvry, A., Emerick, K., Raitzer, D., Sadoulet, E. (2013). Floodtolerant rice reduces yield variability and raises expected yield, differentially benefitting socially disadvantaged groups. Sci. Rep. 3: 3315.

Doni, F., Isahak, A., Zain, C.R.C.M., Ariffin, S.M., Mohamad, W.N.W. and Yusoff, W.M.W. (2014). Formulation of Trichoderma sp. SL2 inoculants using different carriers for soil treatment in rice seedling growth. Springerplus, 3: 532.

Fukao, T., Yeung, E. and Bailey-Serres, J. (2011). The submergence tolerance regulator SUB1A mediates crosstalk between submergence and drought tolerance in rice. Plant Cell, 23: 412427.

Gusain, Y.S., Singh, U.S. and Sharma, A.K. (2014). Enhance activity of stress related enzymes in rice (Oryza sativa L.) induced by plant growth promoting fungi under drought stress. Afr. J. Agric. Res. 9: 1430-1434.

Harish, S., Saravavakumar, D., Radjacommar, R., Ebenezar, E.G. and Seetharaman, K. (2007). Use of plant extracts and biocontrol agents for the management of brown spot disease in rice. Biocontrol, 53(3): 555-567.

Harman, G.E., Howell, C.R., Viterbo, A., Chet, I. and Lorito, M. (2004). Trichoderma species opportunistic, avirulent plant symbionts. Nat. Rev. Microbiol. 2:43-56.

Howell, C.R. (2003). Mechanisms employed by Trichoderma species in the biological control of plant diseases: the history and evolution of current concepts. Plant Dis. 87: 4-10.

Ismail, A.M., Singh, U.S., Singh, S., Dar, M.H. and Mackill, D. (2013). The contribution of submergence-tolerant 
(Sub1) rice varieties to food security in flood-prone lowland areas in Asia. Field Crops Res. 152: 83-93.

Jones, L., Provins, A., Holland, M., Mills, G., Hayes, F., Emmett, B., Hall, J., Sheppard, L., Smith, R., Sutton, M., Hicks, K., Ashmore, M., Haines-Young, R. and Harper-Simmonds, L. (2014). A review and application of the evidence for nitrogen impacts on ecosystem services. Ecosyst. Serv. 7: 76-88.

Kumari, P. (2016). Drought management in rice (Oryza sativa L.) with the use of hydrogel and bio-agent (Trichoderma) under Varanasi condition of eastern Uttar Pradesh. M.Sc. (Ag.) Thesis. Banaras Hindu University, Varanasi, India pp175.

Kumawat, G.L., Biswas, S.K. and Srivastava, S.S.L. (2008). Biochemical evidence of defense response in paddy induced by bio-agents against brown leaf spot pathogen. Indian Phytopath., 61 (2): 197-203

Martínez-Medina, A., Roldán, A., Albacete, A. and Pascual, J.A. (2011). The Interaction with Arbuscular Mycorrhizal Fungi or Trichoderma harzianum alters the shoot hormonal profile in melon plants. Phytochemistry, 72:223-229.

Pantuwan, G., Fukai, S., Cooper, M., Rajatasereekul, S., O'Toole, J.C. and Basnayake, J. (2004). Yield response of rice (Oryza sativa L.) genotypes to different types of drought under rainfed lowlands. Field Crops Res. 73: 181200.

Pantuwan, G., Fukai, S., Cooper, M., Rajatasereekul, S., O'Toole, J.C. and Basnayake, J. (2001). Yield response of rice (Oryza sativa L.) genotypes to different types of drought under rainfed lowlands. Field Crops Res. 89: 281297.

Singh, R., Singh, Y., et al., (2016). From QTL to variety-harnessing the benefits of QTLs for drought, flood and salt tolerance in mega rice varieties of India through a multi institutional network. Plant Sci. 242: 278-287.

Windham, M.T., Elad, Y. and Baker, R. 1986. A mechanism for increased plant induced by Trichoderma spp. Phytopathology, 76:518-521.

Xiao, B.Z., Chen, X., Xiang, C.B., Tang, N. Zhang, Q.F. and Xiong, L.Z. (2008). Evaluation of Seven Function-Known Candidate Genes for their Effects on Improving Drought Resistance of Transgenic Rice under Field Conditions. Molecular Plant: 1-11.

Zaidi, M.W., Singh, M., Kumar, S., Sangle, U.R., Nityanand, Singh, R., Sachitanand, Prasad, Rameshwar, Singh, S.S., Singh, S., Yadav, A.K., Singh, A., Showkat, A., Singh, U.S (2018). Trichoderma harzianum improves the performance of stresstolerant rice varieties in rainfed ecologies of Bihar, India. Field Crop Research, 220: 97-104.

\section{How to cite this article:}

Dinesh Rai. 2018. Performance of Stress Tolerant Rice Varieties Treated with Trichoderma spp. under Rainfed Condition in Bihar, India. Int.J.Curr.Microbiol.App.Sci. 7(09): 368-378. doi: https://doi.org/10.20546/ijcmas.2018.709.045 